\title{
Minding the Gaps: The Role of Finnish Civil Society Organizations in the Labour Market Integration of Migrants
}

\author{
Ilona Bontenbal ${ }^{1} \cdot$ Nathan Lillie $^{1}$ (D)
}

Accepted: 9 February 2021/Published online: 17 March 2021

(C) The Author(s) 2021

\begin{abstract}
The growing role of civil society organizations (CSOs) in welfare service provision is sometimes portrayed as a threat to welfare state universalism in Nordic societies. In Finland, CSOs co-produce integration services alongside comprehensive official integration programmes, compensating for gaps and shortcomings in those services. We identify three "gaps", which are (1) limited availability of services in terms of time and target group, (2) lack of direct labour market contacts and (3) limited flexibility to serve individual needs. We assess how CSOs target these gaps with their service offerings through qualitative interviews with policy implementers, CSO workers and migrants. However, CSOs' role in labour market integration is inherently limited by their services being small scale, short term and project based. We find that due to their independence and limited role, CSOs operate synergistically with official services, extending rather than undermining universalism.
\end{abstract}

Keywords Migrant labour market integration - Active labour market services for migrants · Co-production · Role of CSOs - Welfare state universalism

\section{Introduction}

Over the past three decades, the number of migrants coming to Finland has increased dramatically. Despite the provision of extensive labour market integration support services, un- and underemployment among migrants has

Ilona Bontenbal

Ilona.bontenbal@jyu.fi

University of Jyväskylä, Jyväskylä, Finland remained high. Migrant labour market integration policy in Finland is provided through universalist bureaucratic social service structures, which aim at making available a high level of active labour market services for the target population of working age unemployed migrants. Social services are largely the prerogative of the state (Salamon and Anheier 1999: 229) but CSOs also play a secondary, though important, role (Numerato et al. 2019; Sama 2012). When the state together with citizens, via civil society organizations (CSOs), participate in the provision of services, such as integration services, this is known as coproduction (Brandsen and Pestoff 2006). As Bovaird and Loeffler (2012) point out, co-production can be conceptualized as a shift from 'public services for the public' towards 'public services by the public'.

The recent increase in the number of arriving asylum seekers to Finland since 2015 in particular has fuelled growing demand for migrant labour market integration services, highlighting several shortcomings of official services, to which CSOs have responded by expanding their own labour market services. We identify three gaps in the official integration efforts: (1) limited availability of services in terms of time and target group, (2) lack of labour market connections, and (3) limited flexibility to serve individual needs. We show how CSOs have, as co-producers, stepped in to fill these gaps.

The literature generally tends to focus on the role of either official services or CSOs in the integration of migrants. The intersection between these has not been extensively researched, which is why it is of special interest to us. The role of CSOs in universalist welfare states is of concern, because of the possibility that it is a symptom of policy failure (see Silvasti 2015, for this argument applied to food aid). This would be the case if the state active labour market policy were insufficiently 
resourced to address the problem of poor migrant employment outcomes. CSOs step in to alleviate the unmet community needs and/or social problems which result. Alternatively, one might regard CSOs as pushing themselves into this role, giving the state an excuse to withdraw, perhaps by "outsourcing" service provision to CSOs. The first and second possibilities are similar, only with different drivers (neglect in the first case, intention in the second). A final possibility, which we argue is the case in Finland, is that there are inherent limits to state capacities, even in universalist systems, and in this context CSOs as co-producers step in to fill the gaps. We show that the growing role of CSOs in Finland is not a result of state withdrawal or a reduction in universalism, but rather a reaction to the rapidly rising and fragmenting demand for labour market services, which requires extending services quickly and flexibly, in a manner inherently difficult for state bureaucracies, but possible for CSOs. While the growing role of CSOs raises challenges and concerns because of their limited capacity and organizational instability, we consider that in the case of Finnish migrant integration services, CSOs, through co-production, compensate for inflexibility implicit to welfare state universalism.

We base our analysis on interviews with 60 migrants, refugees, and asylum seekers, 10 integration policy implementers, and $20 \mathrm{CSO}$ representatives.

\section{The State and Civil Society: Pros and Cons of CSO Involvement in co-Production of Services}

For the background of our study we draw on the literature of state-CSO cooperation and especially co-production. We identify the main pros and cons of civil society participation in co-production of services, which we then use to illustrate the role that CSOs in Finland have in compensating for gaps in labour market integration services. CSOs have an important role in the provision of labour market integration services in many countries. In, for example, Greece or the Czech Republic, CSOs take over substantial state functions, compensating for a lack of state involvement in this sector (Numerato et al. 2019). Similarly, in UK and Germany, CSOs work as service providers in disciplining the unemployed, following state priorities of marketization (Greer et al. 2017). Elsewhere in this issue, Calò et al. (2021) find that the services provided by third sector organizations in labour market integration in the UK, remain limited, especially in terms of formal employability and skills development services.

Universalism is a multifaceted concept (Anttonen et al. 2012), but in the context of welfare service delivery, it implies policies which support equality through a uniformity of high standards (Esping-Andersson 1990).
Characteristics of universalism include, for example, that means testing for eligibility is limited, receiving government services is not stigmatized, and the quality of services is sufficient so that not just the poor make use of them. If CSOs are undermining universalism, this implies that needed government services are either becoming unavailable, or their quality is declining. We show that this is not the case and instead we find "co-production" of labour market services meaning that the involvement of CSOs diversifies and improves the offering, mobilizes new resources, and better involves recipients in the process. Despite complaints about specific issues, migrants still perceive the government services to be of good quality. CSOs do not provide general services, but rather target specific needs that are underserved by the state. These gaps arise due to the rapidly changing nature and importance of the demands put on the Finnish labour market integration programmes, rather than a lack of resources per se. Universalist programmes are by necessity limited in their flexibility, and CSOs' role in Finland is to fill the gaps which emerge as a result.

"Co-production" involves a synergetic relation between the activities of government and of citizens, such as selforganizing communities of individuals who come together to produce a shared outcome (Pestoff 2012). In co-production, citizens actively participate in shaping services instead of merely passively receiving the service (Brandsten and Honingh 2016). Reasons to increase citizens' involvement in public services include improving service quality, providing more differentiated services and more choice, making public services more responsive and cutting costs (Bovaird and Loeffler 2012: 7). By involving citizens, governments attempt to improve the efficiency of public services, reform welfare states and promote social goals such as democracy and citizens' empowerment (Pestoff 2006, 2012).

This discussion of co-production emphasizes positive aspects of state-civil society engagement, with each group able to play to its strengths and compensate for the others' weaknesses (Bovaird and Loeffler 2012). The state has resources, authority, and legitimacy, and can guarantee that labour market programmes are universally available. CSOs, on the other hand, can respond to special and emerging needs. They are able to mobilize resources, such as volunteers, to which the state does not necessarily have access, and communicate organically with the communities in which the CSOs are embedded. CSOs have the possibility to recognize grass-root needs and to reach certain target groups more efficiently (Lautiola 2013: 56). Moreover, CSOs compensate for gaps by offering more flexible and demand-responsive labour market services than state bureaucracies. They can tailor their services more quickly to the circumstances of their migrant recipients and can be 
more migrant- and migrant community directed. As Häikiö and Hvindon (2012) point out, societal diversity introduces tensions into the practice of (Nordic) universalism. We assert that under certain conditions, CSOs alleviate the problems raised by this tension, by compensating for the gaps and inflexibility which tend to emerge. Under a "coproduction" dynamic, state and civil society each has a comparative advantage, and synergistic roles to play.

However, assigning or allowing CSOs to assume responsibility for state services can create unintended dynamics and perverse incentives. If government pressure, metrics and tendering processes, undermine CSO goals, this may shift their priorities away from serving their clients (Evans et al. 2017). Finnish discussions of state-CSO cooperation warn of a threat to welfare state universalism posed by the growing role of CSOs in the provision of welfare services. A basic assumption inherent in universalism is that the welfare state can and should attend to the needs of all citizens adequately. If CSOs must intervene to attend to unmet welfare needs, this is a symptom of poorly designed or under-resourced social policy. In other words, in delivering aide, CSOs "normalize the abnormal", making welfare dependant on good will rather than being a right (Silvasti 2015). There is the danger that when CSOs are providing services, policy makers will not see it as necessary to use state resources, hoping that CSOs will step in. While relying on the third sector may seem an inexpensive way to address social issues, CSOs do not have the authority, resources, or scope to guarantee help for all those in need. Furthermore, as private actors, CSOs have discretion about whom to help and how (Martinelli 2012). Therefore, increased reliance on CSOs can serve as a cover for state withdrawal, and result in sporadic and unpredictable levels of service provision.

One solution might be for the universalist state to contract services from CSOs, thus taking advantage of state resources and authority while also mobilizing the unique abilities of CSOs. The literature on this as relates to active labour market policies warns of organizational pathologies and perverse incentive regimes. Greer et al. argue that state withdrawal from labour market service provision raises the prospect of deliberately hiding service cuts behind outsourcing of services to CSOs. CSO service provision has been a major way in which active labour market policies have been organized in, for example, the UK, Germany and Denmark, where the state has created pseudo-"markets" for active labour market services. CSOs are rewarded for moving unemployed into employment as quickly as possible. However, those most in need of active labour market policy services are also furthest from the labour market, thus requiring the most time and resources to help. Perverse incentive regimes develop, causing CSOs to focus their attention on helping the "best" clients find jobs quickly (i.e. "creaming" or "cherry picking"). These dynamics are similar whether the services providers are for-profit or third sector, as the process tends to make CSOs behave more like private firms. If they are simply delivery systems for state policy, they must follow the bureaucratic and political priorities of the government, as defined in, for example, the tendering process needed to access state resources (Greer et al. 2017). The specifics of the funding process, and its influence on CSO behaviour are therefore important.

These issues are not exclusive to tendering processes, as the flip side of receiving funding from the state is a danger of mission-drift and co-optation. State agencies provide resources, but these are subject to conditions which restrict CSO autonomy. In the case of co-production, a part of the CSOs' advantage is their ability to act autonomously, i.e. to identify particular needs and innovate solutions, without the need for broader policy change (Pestoff 2012). To the extent CSOs' resources come from elsewhere, such as from charitable giving, the church, or the EU, they retain independence from the state. There is a strategic imperative for CSOs to balance the requirements of staying "on-mission" with the need to raise money and satisfy financial stakeholders (Dolnicar et al. 2008), implying that a broad funding base allows greater CSO autonomy. Allowing space for CSO's own goals to drive their role in service delivery may have better outcome than systems driven by state-created markets and metrics because it allows them to identify and react more quickly to new needs, to organically interact with migrant communities, and to mobilize community resources.

\section{The Finnish Labour Market Integration System and its Coverage Gaps}

While Finland has a robust active labour market policy and labour market integration infrastructure, it nonetheless faces difficulties in integrating migrants into the labour market. Finland hosts few migrants (c. $8 \%$ of population) compared to most other European countries. Despite welldeveloped labour market integration programmes and comparatively high active labour market policy spending (OECD stat 2017), foreign-born individuals, especially third country nationals, have much higher unemployment rates than natives (Belegri-Roboli et al. 2018). Nonetheless, Finland's active labour market policy and labour market integration measures, such as the preparing of individual integration plans, improve employment outcomes for migrants (Sarvimäki and Hämäläinen 2016), and many migrants also perceive the state programs as beneficial (Bontenbal and Lillie 2019a). The main actors managing the official government-organized integration programmes are employment offices (TE office) and local 
governments (municipalities). In general, integration training is more widely available to more categories of migrants than in other European countries, in that not only refugees but also other categories of migrant are included (Bontenbal and Lillie 2019b).

The labour market integration programmes ensure that unemployed job-seeking migrants receive an individual integration plan and can attend integration training for 3-5 years after migration. However, after this, few integration services are available. Employed migrants and migrants that do not (yet) live in Finland permanently such as asylum seekers, international students or seasonal workers, are not automatically entitled to labour market integration services. Moreover, there is no obligation for the TE office or municipality to ensure that the services offered when drawing up the integration plan are actually available when the migrant needs them (Arajärvi 2009: 66). (GAP: limited availability).

Official integration training generally consists of language learning, vocational training, work trials, mentoring, labour market information and cultural skills classes (Maahanmuutto ja kotouttamisen suunta 2015: 80, 83). In practice, integration training emphasizes language learning heavily emphasized, comprising about $2 / 3$ of the programme. However, despite the heavy emphasis, results have been poor: in 2016 more than 4/5 participants failed to attain the target level of B1.1. in the Common European Framework for Reference for Languages. (OECD 2018: 27-28.) This is thought to relate to a lack of sensitivity in the course design to the diverse individual backgrounds and life situations of migrants (Kokeilulakia valmisteleva strategiatyöryhmä 2009: 4). Furthermore, level B.1.1. is sufficient for certain jobs and life situations, but insufficient for others (Lehtimaja 2017).

Given that the TE office programs are based on individual integration plans, one would expect that these would be based on a detailed assessment of the individual migrants' education and work experiences. However, some migrants report that TE offices are not interested in them or in their skills. For example, TE offices cannot offer personalized help and the kind of services that certain woman with an immigrant background need (Steel and Jyrkinen 2017: 39-40). Moreover, some migrants in the program are not even aware that an individual integration plan has been made for them, and what the plan actually includes (Maahanmuutto ja kotouttamisen suunta 2015: 77; Eronen et al. 2014: 26). Consistent with what Clarke (2011) observes, this suggests the migrants' role is passive and the plans are not always as interactive as they are meant to be. (GAP: limited flexibility to serve individual needs).

Integration services close to the labour market, such as vocational training provided as an active labour market policy, and wage subsidies, facilitate labour market integration best (Maahanmuutto ja kotouttamisen suunta 2015: 87; Aho and Mäkiaho 2017: 10). Thus, earlier research recommends that the connections between integration training and employment opportunities be enhanced (Ala-Kauhaluoma et al. 2018: 127). Especially, the research identifies a need to provide language courses that are intertwined with labour markets needs (Maahanmuuton ja kotouttamisen suunta 2011-2014: 42). However, in 2017 , only $4,9 \%$ of non-EU national public employment service clients participated in subsidized employment, compared to $24,1 \%$ of native-born public employment service clients (OECD 2018: 146). (Gap: Lack of labour market connections).

Besides official integration services, CSOs also have a substantial role in the delivery of active labour market and integration services. Since the depression of the mid-1990s, CSOs have, among other things, provided accessible employment and employment-related support to long-term unemployed (Sama 2012). The Finnish integration legislation reform of 2011 highlighted the importance of the third sector (Lautiola 2013: 15), delegating various integration responsibilities to civil society organizations (Pirkkalainen 2015: 56). The role of CSOs is further emphasized by the national curriculum governing integration training, which encourages training organizers to collaborate with the third sector (Lautiola 2013: 20).

Most migrant organizations, of which there are c. 700-1000 (Finnish Government 2015), seek to help their members integrate while maintaining their ethnic identity (Saksela-Bergholm 2011: 92). Guidance in integration, peer support and language learning are some of the most common services offered by migrant organizations (Ekholm 2015: 27). Some CSOs have recently moved into bidding for government service-provision contracts. Commonly outsourced state activities include running migrant info-centres and job-search activities. CSOs, mostly run by native Finns, also have a central role in the running of asylum centres (Pirkkalainen 2015: 52). Service provision raises the danger that migrant CSOs become public sector integration contractors, resulting in mission drift away from their role as migrant advocates, and from the traditional Finnish third sector associations' role as representatives in political decision-making (Pirkkalainen et al. 2018: 24-31). However, service provision is not a major trend among migrant organizations, due to limited resources and a lack of management manpower (Ekholm 2015; Pirkkalainen 2015: 56). Instead, Finnish CSO funding comes from diverse sources, including membership fees, payments and one-time donations. Organizing events and selling products constitutes another significant income channel (Taloustutkimus 2018). 


\section{Data}

We interviewed 60 migrants, refugees and asylum seekers, 10 integration policy implementers, and 20 CSO representatives. The interviews lasted between 30 and $60 \mathrm{~min}$ and were recorded and transcribed. Information endangering anonymity, such as names, working places, specific study programmes and cities, was left out of the transcriptions. These are also left out of the quotations used in the analysis chapters to highlight the findings. Before the interviews, the participants were provided information verbally and in written form about the research. After this, participants were asked to sign a consent form.

The migrant interviewees were recruited through migrant organizations' mailing lists, Finnish language courses and by using the "snowballing" technique. All the migrants were interviewed face-to-face in Finnish, English, Russian or Arabic. During some interviews, a translator was used. The interviews took place in Helsinki and in medium-sized cities in central, southern and eastern Finland, in libraries, cafes, university spaces and at migrants' homes.

Migrants from 15 different nationalities (Russia, China, Somalia, Ethiopia, Eritrea, Kenya, India, Bangladesh, Vietnam, Nepal, Iraq, Columbia, Syria, Pakistan and Iran) were interviewed. Most arrived in Finland 2014 or later, and had taken part in the official integration training. In total, 23 came as asylum seekers, 13 through family reunification, 6 through marriage, 9 as students, 6 because of Finnish family roots and 3 for employment. All were between 20 and 55 years old. Most were either students or unemployed at the time of the interview. This is related to the way Finnish integration policy steers migrants towards re-education rather than recognizing previous skills and qualifications. Very few were working in the field in which they received their education in their country of origin, despite most having a higher education degree from their country of origin. Of those with work experience in Finland, most of it was in internships and work trials, rather than regular employment.

Besides migrants, 10 implementers of official integration training were interviewed, from municipal integration services, the employment office, higher education institutions, asylum seeker reception centres and training institutes offering integration classes. All had hands-on experience with the implementation of official integration services or their outcomes.

The CSO interviews were conducted in Jyväskylä and Helsinki, targeting local organizations organizing labour market integration activities for migrants. Also, representatives of national-level organizations were interviewed, mostly in Helsinki. These included both migrant and native led organizations.

We used theory-guided thematic content analysis. The gaps in integration services, retrieved from previous research and introduced in chapter 3, guided the coding of data (by using QDA miner software) and the thematic analyses. They enabled the grouping of research material into useful entities. These entities also form the subchapters of the following section of the article.

\section{Minding the Gaps: how can CSOs Compensate for Short Comings in Official Integration Services?}

In this chapter, we analyse what factors are enabling CSOs to fill the previously identified gaps left by official services in the labour market integration of migrants (limited availability, lack of labour market contacts and limited individualization). These factors are often manifested in language learning, which is why it is used as an example throughout the analysis chapter. We further analyse whether the role of CSOs as co-producers threatens welfare universalism.

\section{Gap: limited Availability}

Official integration services are only available for a limited group of migrants for a limited time period. As the executive director of one of the CSOs we interview notes "We [in Finland] have this great thing which is the integration training [official TE integration services]. It generally consists of one year of language training. But for those for whom the one year is not enough to achieve the kind of language skills that enable getting straight into the labour market, higher education, or vocational education there is a gap and transition period, in which people get stuck" (CSO representative, executive director). The migrant interviewees, as well CSO representatives, emphasize that Finnish language is difficult, and few migrants have any skill in it prior to coming to Finland. Many migrants find that the 3 years of language study in the official programme is not enough time to learn the Finnish properly: "The TE office told me that I can no longer take Finnish language courses, but I need them. My language skills are poor" (Migrant, Iraq, F, age 54).

We find that this gap has been noted and addressed by CSOs, who offer various types of services and activities that aim to prolong the availability of integration services: CSOs, for example, offer various language learning opportunities that migrants can join after the official language services are no longer available for them. By doing this, CSOs are building a bridge between the official integration services and employment, especially for those 
migrants who after finishing their integration training do not straight away enter the labour market. As one CSO representative notes: "We have found it problematic that Finnish language teaching stops after the integration period ends. People are left hanging. Their language skills are not good enough for them to get work or start studying" (CSO representative, project manager). In this sense, CSOs function temporally as an extension to official integration services.

Moreover, CSOs also offer services to a wider target group than the official services. Thus, also those for who official services are not available due to, for example, them already being employed, can find support from CSOs. As one of the migrant interviewees notes: "Finland is quite concentrated on those that are coming and not working yet. Helping them a lot. But for us (i.e. employed migrants) it kind of reaches a bottleneck" (Migrant, China, F, age 26). The focus of official services is thus strongly on employment, and once a person is employed, she/he is considered integrated. However, many migrants find they cannot, for example, learn Finnish on the job, for a variety of reasons. Many workplaces operate in English, migrants have little contact with native speaking colleagues, and many employers do not provide language lessons as a benefit. Because of this, employed migrants sometimes turn to CSOs.

Although the target audiences of CSO labour market activities are wider than those of official integration services and almost anyone asking for help can get it, in practice most activities are organized independently and on a small scale, which curtails utility. One central challenge that CSOs face is that most of the services they provide are project based and thus only available for a limited time period. This hinders their possibility to extend the availability of services. As one CSO employee notes: "We receive funding but it is not permanent and it changes from project to project and that is a challenge that we do not have permanent services to offer-projects and employees come and go and then we start again from the beginning -” (CSO representative, career councillor). Projects last for some period, after which the services are no longer available but instead new projects often start from scratch. This development has been going on since the 1990s: funding for CSOs has been moved away from continuous yearly funding towards short-term project funding (Seppo 2012).

Some CSO representative interviewees were especially critical about the lack of interest from municipalities to capitalize on good practices developed during projects. This indicates a lack of tools and methods for applying and utilizing the possibilities of co-production, also noted in previous research (see Tuurnas 2015). Some noted that there should be special separate funds to enable the continuation and institutionalization of good practices. Since continuity of services is not guaranteed, there can also be no straight path from official services to CSO services. Yet, the fact that most CSO labour market services are project based also permits flexibility which ensures that even as the labour market integration needs of the migrant population change too quickly for formal structures to adapt, CSOs are nonetheless able to provide at least some level of services to underserved groups.

Despite this, CSOs do not, and for some part cannot, replace official universal services. Many of our interviewees had little or no experience with labour market integration programs run by CSOs, although they were generally familiar with the official services (even those who had made no use of these). Some migrants were reluctant to join or participate in CSOs, perhaps due to not having any experience of participating in CSOs in their country of origin, and associating it with illegal or dangerous activity (Ekholm 2015: 45). Some of the migrant interviewees also report that they had sought assistance from CSOs but were discouraged by language barriers, or not finding the right contact person.

\section{Gap: Lack of Direct Labour Market Contacts}

Official integration services have been criticized for not having a direct enough applicability to the labour market that they are supposed to prepare the migrants for. Official integration training is for the most part organized in a classroom setting among other migrants. This becomes problematic because in previous research, lack of work experience, knowledge of the labour market and social networks have been identified as critical barriers to labour market integration for migrants (Bontenbal et al. 2019).

We find that to mind this gap, CSOs have started to offer more labour market integration-related services. CSOs have recognized a need to connect labour market integration with social and cultural activities: "Although employment related activities are not our main objective, because employment is such an important part of people's lives and especially for migrants' employment, it is in my opinion the best way of integrating" (CSO representative, coordinator). Whereas cultural integration and learning the language are still among the central integration activities for migrants, also more labour market integration-related targets are being set. Such activities include, for example, helping in the job search through organizing CV workshops, prepping interview skills, helping in writing job applications, and organizing labour brokerage; providing information about workers' and employers' rights and duties, legislation, available jobs and adjusting to the work place; helping with bureaucratic issues such as work permits, certificates, diplomas, qualifications, subsidies and tax-related issues, and organizing trainings such Hygiene 
Passport and Safety card trainings. These activities are generally offered to small groups (c. 5-30) of migrants as fixed-period projects, which limits their overall role.

Whether a shift towards these services will lead to mission-drift, due to labour market integration being emphasized on the expense of overall integration, remains to be seen. The experience of the interviewed migrants seems to be that at least in their current form labour market integration activities are not threatening other integration services offered by CSOs. In fact, we find that based on migrant experiences, the CSOs' ability to compensate for a lack of labour market contacts is still limited: many migrant interviewees state that although CSOs have helped them in social integration, such as providing information about Finnish culture, norms and legislation, their services have not been as useful in labour market integration. Moreover, the previously mentioned labour market integration services offered to migrants do not link migrants directly to the labour markets. They function more to increase the migrant's human capital for, and increase their knowledge of, the labour market instead of directly developing contacts in it and thus have much of the same weakness as official integration services.

Thus, some CSOs try to create opportunity to build social networks and find internships. Previous research shows that networks play an important role in finding employment (Ahmad 2014; OECD 2018: 35). Many of the migrant interviewees report meeting and befriending Finns, who participate, for example, as volunteers in language learning, during CSO activities: "I have gotten advantages that government can't provide: Practicing language and meeting people which could help you in the integration-" (Migrant, Somalia, M, age 20). Because official integration training is generally organized in a classroom setting, participation also limits contacts with native Finns and the ability to practice language skills in "real-life" settings.

Furthermore, CSOs also offer migrants direct employment opportunities and opportunities for internships and volunteering within their own organizations. This creates direct contacts to the labour market: "We help women find work, internships and work practices. Many women have first been in our Finnish language classes and after that they come work for us as interns and then through the wage subsidy programme" (CSO representative, executive director). According to the interviewees, offering internships is important in helping migrants familiarize themselves with Finnish working life and also supports networking. Although the non-profit sector in the Nordic countries has traditionally not had a significant role in providing employment opportunities, because most work is done by volunteers (Pirkkalainen et al. 2018: 28; Saukkonen 2013: 10; Salamon and Anheier 1999: 241), its role as an employer has grown quickly, especially in social service organizations (Ruuskanen et al. 2013). Compared to natives, for migrants, CSOs offer significantly greater employment opportunities, and often serve the role of being a first experience in the Finnish labour market (Pirkkalainen 2015: 52; Ekholm 2015: 33). These jobs are precarious, however, since many are project based (Pirkkalainen et al. 2018: 28).

\section{Gap: Limited Flexibility to Serve Individual Needs}

Because of the emphasis on individual integration plans, Finnish labour market integration is more individualized relative to other European countries. Nonetheless, the principle of individualized plans is often difficult to realize in practice, in particular given the extreme diversity of the migrant population, along just about every possible dimension, including culture, professional and language needs and educational background. Despite the individual integration plan being the starting reference point for the official integration process, in practice migrants with different backgrounds and needs are often lumped together in similar courses and programmes.

Language classes offer a case in point, since migrant language learners include some adults who have yet to learn to read and write, all the way to highly skilled professionals. As one interviewee told us: "Sometimes I feel that the courses have been predesigned and people have to modify their needs to their course, instead of the courses having to modify their needs to the participants" (Municipal integration staff). While some interviewees found the language courses that are part of official integration training too easy, others found them too difficult. One interviewee told us "When I first went to the course, by pen broke all the time. I did not know how to use a pencil because I did not go to school in my home country. No one noticed this" (Migrant, Iraq, F, 31). On the other hand, for many the Finnish level did not advance far enough, and the problem was that no advanced courses were available. Some migrants also complained that due to old age they were unable to learn the language in the required three years, and they would have benefitted from additional services for older migrants.

CSOs respond to these needs with specific courses and more individualized support. For example, CSOs offer language learning in a variety of settings, including not only traditional classroom settings, but also peer-to-peer learning. Some migrant interviewees emphasize that through CSO activities they have been able to practice their language skills "without having to be afraid of making mistakes" (Migrant, Syria, F, age 33).

CSOs also offer low-threshold participation opportunities in order to more flexibly meet individual needs. Some migrants find it easier to contact CSOs than public officials. 
One CSO representative, for example, noted that " $A$ significant pull-factor is when we hire individuals with a migrant background. Many people will follow because they think that people with a migrant background can understand them better than some social worker" (CSO representative, executive director). Especially those organizations run by migrants or that employ migrants can be easier for migrants to contact compared to government officials, due to trust and language issues.

Because of more organic connections to the communities they serve, CSOs are also more likely to offer services in migrants' own languages. Our migrant interviewees often noted dissatisfaction with the unavailability of official services in their own language. Although TE offices offer information sessions in common migrant languages, they cannot offer support in all languages. CSOs fill this gap to some extent through migrant volunteers. Many of the CSO interviewees note that people with a migrant background have useful cultural knowledge, language skills and networks, as well as personal experience with the migration and asylum application process.

The TE office's services are limited by policy but CSOs will sometimes go further in terms of offering hands-on support. While the official integration services help in finding vacancies, and writing CVs and application letters, they are unlikely to actually apply for the work on the migrants' behalf. Some CSO representatives note that they occasionally do everything for the migrants, including writing CVs and application letters and even contacting employers on their behalf. This is especially useful for migrants who do not speak Finnish well enough to contact the potential employer him/herself.

Furthermore, we find that CSOs offer more tailored support for stay-at-home parents, and women in general. The CSO interviewees bring up that in some cases women need different or additional support in labour market integration than men. Women more often care for young children, which makes participation in official integration training difficult. To fill this gap, many CSOs offer services, such as language classes and employment information sessions where patents can bring their children along. Childcare services are offered for the duration of the activities, or sometimes even home visits are organized. This is resource-intensive, but useful to help those that otherwise remain outside the reach of integration services. Moreover, in some cases separate courses are needed for men and women due to cultural practices. Therefore, some CSOs offer language classes that are only meant for women.

The examples provided in this chapter illustrate that CSO can, to some extent, offer more individualized support for migrants. However, some migrants also criticized CSO offerings, maintaining they were not rigorous or advanced enough. Some interviewees, for example, note that in their experience offering the possibility to take children with you to language class can lead to a less focused learning environment. Some found CSOs' offerings to be mainly targeted at beginning language learners, complaining that no courses for advanced learners are available. "It's a pity that no courses are offered to those who already speak Finnish well. We have to find ways to improve ourselves but if you do not have Finnish friends or a Finnish partner it is very difficult to improve your language skills, especially if you do not work" (Migrant, Russia, F, 42). Courses by the open university and learning institutes are not free of charge, which is why many migrants are not able to participate: "I always wanted to go to an advanced Finnish course at university but it was not free of charge and I did not have enough money" (Migrant, China, F, age 31). Therefore CSOs have an important role since their language courses are often free of charge.

\section{Discussion}

Finnish CSOs increasingly offer small-scale labour market integration services, such as job brokerage, labour market information classes and job search assistance, because they perceive an unmet demand. The CSOs compensate for gaps in official integration programmes' service coverage, offering more differentiated, flexible and innovative labour market services, which are sometimes more closely tailored to the situations of the recipients. They respond to special and emerging needs, compensating for gaps in official integration services coverage, a lack availability of services, a lack labour market connections and a lack of possibility to serve individual needs. The role of CSOs is especially important for those who cannot participate in official integration training.

However, due to their limited nature, CSOs cannot provide a comprehensive solution to migrant labour market integration needs. CSOs do not substitute for the offerings of the official integration programmes. While the official programmes are back by a high level of resources, and are universally available to unemployed migrants who are considered "permanent", CSO projects are small scale and time limited. Many migrants still do not seem to be aware of CSO services or have experience with them, underlining their secondary role. This also underlines the limitation of the study: we largely rely on migrant perceptions, which represent the views of only one stakeholder. To more accurately assess the effectiveness of integration programmes, a pedagogical perspective and thorough review of employer requirements, would be needed as well.

There has been a concern about the growing role of CSOs, because of the potential for undermining Finnish 
welfare state universalism. Universalism, however, also implies a uniform high level of services available to the entire target population, which implies inflexibility, in that it is difficult to account for the needs of specific groups. To provide a similar level of high-quality services over the whole of the eligible population requires a relatively topdown and inflexible integration framework. If the same level of services must be offered across the whole country, reforms are necessarily large, expensive, and politically complicated, and can only occur occasionally. Some migrant groups are not eligible, or have life situations which do not fit the design of the programmes. These gaps push CSOs to take a role as co-producers, responding more quickly and innovatively to new situations. While there are legitimate concerns about CSO "mission-drift", co-optation, and pressures on welfare universalism resulting from third sector growth, the dominant trend has been one of synergistic cooperation. Partly this relates to the fact the state still has a sizeable role, and its retreat from active labour market policy involvement has been limited. Outsourcing labour market integration services to CSOs has not been a major trend. Unlike the state-run services, which aspire to be universally available to the target population, the CSOs offer services to limited groups in limited situations.

Finnish CSO funding sources are diverse, and the Finnish state has not tried to control CSO migrant integration activities by introducing pseudo-markets. Funding mechanism do push the labour market integration services of CSOs mainly towards short-term projects and helping those already living as permanent citizens of municipalities, which is a recognized as a problem. We find, however, no evidence of CSOs reorienting their focus to "game" the funding system, nor do CSO staff mention pressure to do this. CSOs shift towards labour market services seems to come from "within", and from migrant experiences of the gaps left in official services, rather than from above, through incentive regimes. The increased focus on labour market integration could guide existing resources away from general social integration services, which might be considered mission-drift. However, so far this has not happened.

Our findings suggest that in the context of a political commitment by the state to provide active labour market programmes for migrants, CSO activities tend to extend rather than undermine universalism. CSO organizational independence is also important; governance and funding processes which allow CSOs to shape their own priorities allow them to identify and respond to gaps which emerge in government provided services. In this Finnish context, these factors support co-production of labour market services for migrants in a manner which complements but does not undermine universal state-provided integration services.

Acknowledgements We thank Dino Numerato and Francesca Calò for their comments on the text, and Simone Baglioni for his guidance of the research project collecting the data, as well as the SIRIUS project network for providing a supportive research context. We also thank our many interviewees who took the time to explain the workings of Finland's labour market integration policy, and their experiences with it.

Funding Open access funding provided by University of Jyväskylä (JYU). We acknowledge the financial assistance of a European Union, Horizon 2020 Research programme H2020-SC6-REVINEQUAL2017 Project reference: 770515.

\section{Declaration}

Conflicts of interest The authors declare that they have no conflict of interest.

Open Access This article is licensed under a Creative Commons Attribution 4.0 International License, which permits use, sharing, adaptation, distribution and reproduction in any medium or format, as long as you give appropriate credit to the original author(s) and the source, provide a link to the Creative Commons licence, and indicate if changes were made. The images or other third party material in this article are included in the article's Creative Commons licence, unless indicated otherwise in a credit line to the material. If material is not included in the article's Creative Commons licence and your intended use is not permitted by statutory regulation or exceeds the permitted use, you will need to obtain permission directly from the copyright holder. To view a copy of this licence, visit http://creativecommons. org/licenses/by/4.0/.

\section{References}

Ahmad, A. (2014). "Since many of my friends were working in the restaurant": the dual role of immigrants' social networks in occupational attainment in the Finnish labour market. Journal of International Migration and Integration, 16, 965-985.

Aho, S., and Mäkiaho, A. (2017). Maahanmuuttajat ja työvoimapoliittisten toimenpiteiden vaikuttavuus. Publication of the Ministry of Economic Affairs and Employment, 27/2017, Helsinki.

Ala-Kauhaluoma, M., Pitkänen, S., Ohtonen, J., Ramadan, F., Hautamäki, L., Vuorento, M., and Rinne, H. (2018). Monimenetelmäinen tutkimus kotouttamistoimenpiteiden toimivuudesta. The Audit Committee of the Finnish Parliament 1/2018, Helsinki.

Anttonen, A., Häikiö, L., Steffánsson, K., \& Sipilä, J. (2012). Universalism and the challenge of diversity. In A. Anttonen, L. Häikiö, \& K. Steffánsson (Eds.), Welfare State, Universalism and Diversity (pp. 1-15). Edward Elgar.

Arajärvi, P. (2009). Maahanmuuttajien työllistyminen ja kannustinloukut. Publication of the Ministry of the Interior, 2/2009.

Belegri-Roboli, A., Michaelides, P., Konstantakis, K., Markaki M., and Marinos, T. (2018). Labour Market Barriers and Enablers. Comparative report on the position of post-2014 migrants, refugees and asylum seekers in the labour market. SIRIUS project.

Bontenbal, I., and Lillie, N. (2019a). The Role of the Third Sector in the Labour Market Integration of Migrants, Refugees and Asylum Seekers in Finland. SIRIUS WP4 national report. 
Bontenbal, I., and Lillie, N. (2019b). Integration of migrants, Refugees and Asylum seekers: Policy barriers and enablers. SIRIUS WP3 integrated report.

Bontenbal, I., Pekkarinen, A-G., and Lillie, N. (2019). Finnish Integration Policies as Barriers and Enablers to Migrant Labour Market Integration. SIRIUS WP3 national report.

Bovaird, T., and Loeffler, E. (2012). From engagement to coproduction: The contribution of users and communities to outcomes and public value. Voluntas: International Journal of Voluntary and Nonprofit Organizations, 23(4), 1119-1138.

Brandsen, T., \& Pestoff, V. (2006). Co-production, the third sector and the delivery of public services. Public Management Review, $8(4), 493-501$.

Brandsen, T., \& Honingh, M. (2016). Distinguishing different types of coproduction: A conceptual analysis based on the classical definitions. Public Admin Rev, 76, 427-435.

Calò, F., Montgomery, T., \& Baglioni, S. (2021). Marginal Players? The Third Sector and Employability Services for Migrants. Refugees and Asylum Seekers in the UK. Voluntas: International Jounral of Voluntary and Nonprofit Organizations.

Clarke, K. (2011). Negotiating migrant community needs through social work research: A Finnish example. Qualitative Social Work, 10(1), 8-27.

Dolnicar, S., Irvine, H., \& Lazarevski, K. (2008). Mission or money? Competitive challenges facing public sector nonprofit organisations in an institutionalised environment. International Journal of Nonprofit and Voluntary Sector Marketing, 13(2), 107-117.

Ekholm, E. (2015). Työtä yhteisön ja yhteiskunnan hyväksi Maahanmuuttajajärjestöt palvelujen tuottajina. Ministry of Employment and the Economy. Corporate 53/2015.

Eronen, A., Härmälä, V., Jauhiainen, S., Karikallio, H., Karinen, R., Kosunen, A., Laamanen J-P., and Lahtinen M. (2014). Maahanmuuttajien työllistyminen. Taustatekijät, työnhaku ja työvoimapalvelut. Publication of the Ministry of Employment and the Economy 6/2014.

Esping-Andersen, G. (1990). The Three Worlds of Welfare Capitalism. Princeton University Press.

Evans, B., Richmond, T., \& Shields, J. (2017). Structuring Neoliberal Governance: The nonprofit sector, emerging new modes of control and the marketisation of service delivery. Policy and Society, 24(1), 73-97.

Finnish Government (2015). Maahanmuuttajien järjestöt tukevat kotouttamista. Retrieved 12.4.2019: https://valtioneuvosto.fi/ artikkeli/-/asset_publisher/1410877/maahanmuuttajien-jarjestottukevat-kotouttamista

Greer, I., Breidahl, K., Knuth, M., \& Larsen, F. (2017). The Marketization of Employment Services: The Dilemmas of Europe's Work-first Welfare States. Oxford University Press.

Häikiö, L., \& Hvindon, B. (2012). Finding the way between universalism and diversity: a challenge to the Nordic model. In A. Anttonen, L. Häikiö, \& K. Steffánsson (Eds.), Welfare State, Universalism and Diversity (pp. 69-89). Edward Elgar.

Kokeilulakia valmisteleva strategiatyöryhmä (2009). Maahanmuuttajien tehokkaan kotouttamisen kolme polkua-Kokeilulailla toteutettava alkuvaiheen ohjauksenmalli Osallisena Suomessa. Proposal by the Strategy work group. Publication of the Ministry of the Interior 33/2009.

Lautiola, H. (2013). Kumppanuutta kotouttamisen kentillä. Esimerkkejä järjestöjen ja viranomaisten yhteistyöstä kotouttamisessa. Kieli, koulutus ja yhteiskunta, October 2017.

Lehtimaja, I. (2017). Korkeakoulutetun maahanmuuttajan oikeus oppia suomea. Kieli, koulutus ja yhteiskunta, 8, 5.

Martinelli, F. (2012). Social Innovation or Social Exclusion? Innovating Social Services in the Context of a Retrenching Welfare
State. In H.-W. Franz, J. Hochgerner, \& J. Howaldt (Eds.), Challenge Social Innovation. Springer.

Maahanmuuton ja kotouttamisen suunta 2011-2014 (2015). Ministry of the Interior and Ministry of Economic Affairs and Employment. Publication 2/2015, Helsinki.

Numerato, D., Čada, K., and Hoření, K. (2019). Civil society enablers and barriers. SIRIUS WP4 integrated report.

OECD stat (2017). Public expenditure on activation policies in 2017. Retrieved 23.3.2020 https://www.oecd.org/employment/activa tion.htm.

OECD (2018). Working Together: Skills and Labour Market Integration of Immigrants and their Children in Finland. OECD Publishing.

Pestoff, V. (2006). Citizens and co-production of welfare services. Public Management Review, 8(4), 503-519.

Pestoff, V. (2012). Co-production and third sector social services in Europe: Some concepts and evidence. Voluntas: International Journal of Voluntary and Nonprofit Organizations, 23, $1102-1118$.

Pirkkalainen, P. (2015). Maahanmuuttajajärjestöt kolmannen sektorin muutoksessa. Vertaistuesta ja vapaaehtoisuudesta viranomaisyhteistyöhön. Kansalaisyhteiskunta, 1, 51-73.

Pirkkalainen, P., Abdirizak, M., \& Aaltio, I. (2018). Third Sector hybridization and migrant integration: Cases of two migrant youth organizations in Finland. Electronic Journal of Business Ethnics and Organizational Studies, 23(2), 24-33.

Ruuskanen, P., Selander, K., and Anttila, T. (2013). Palkkatyössä kolmannella sektorilla. Työ- ja elinkeinoministeriön julkaisuja. Työ ja yrittäjyys 20/2013. Helsinki.

Saksela-Bergholm, S. (2011). Maahanmuuttajayhdistysten työllistymistä tukeva toiminta. In Helander, M. (ed.) Totta toinen puoli? Työperäisen maahanmuuton todelliset ja kuvitellut kipupisteet. Svenska social- och kommunalhögskolan vid Helsingfors universitet.

Salamon, L., \& Anheier, H. (1999). Social origins of civil society: Explaining the nonprofit sector cross-nationally. Voluntas: International Journal of Voluntary and Nonprofit Organizations, 9(3), 213-248.

Sama, T. (2012). Role of NGOs in the implementation of active labour market policies: The case of Finland and Sweden. International Journal of Leadership in Public Services, 8(3), 121-143.

Sarvimäki, M., \& Hämäläinen, K. (2016). Integrating immigrants: The Impact of restructuring active labor market programs. Journal of Labor Economics, 34(2), 479-508.

Saukkonen, P. (2013). Kolmas sektori - Vanha ja uusi. Kansalaisyhteiskunta, 1(2013), 6-31.

Seppo, M. (2012). Kansalaisyhteiskunta nyt: Selvitys suomalaisen kansalaisyhteiskunnan toimintaedellytyksistä, tilasta ja asemasta. Kepan taustaselvitykset (Kepa background research) 38 .

Silvasti, T. (2015). Food Aid-Normalising the Abnormal in Finland. Social Policy and Society, 14(3), 471-482.

Steel, T., \& Jyrkinen, M. (2017). Searching for employment: highly educated immigrant women and combined capabilities. Research on Finnish Society, 10(1), 35-42.

Taloustutkimus (2018). Tutkimusraportti. Kansalaisjärjestöjen taloudelliset toimintaedellytykset 2018. VaLa, Allianssi, KANE, Kepa, Olympiakomitea and SOSTE

Tuurnas, S. (2015). Learning to co-produce? The perspective of public service professionals. International Journal of Public Sector Management, 28(7), 583-598.

Publisher's Note Springer Nature remains neutral with regard to jurisdictional claims in published maps and institutional affiliations. 